This item was submitted to Loughborough's Research Repository by the author.

Items in Figshare are protected by copyright, with all rights reserved, unless otherwise indicated.

\title{
Formation of MoOx barrier layer under atmospheric based condition to control MoSe2 formation in CIGS thin film solar cell
}

PLEASE CITE THE PUBLISHED VERSION

https://doi.org/10.1080/10667857.2018.1502512

\section{PUBLISHER}

(C) Taylor \& Francis

\section{VERSION}

AM (Accepted Manuscript)

\section{PUBLISHER STATEMENT}

This work is made available according to the conditions of the Creative Commons Attribution-NonCommercialNoDerivatives 4.0 International (CC BY-NC-ND 4.0) licence. Full details of this licence are available at: https://creativecommons.org/licenses/by-nc-nd/4.0/

\section{LICENCE}

CC BY-NC-ND 4.0

\section{REPOSITORY RECORD}

Ong, Kam Hoe, Agileswari Ramasamy, Panagiota Arnou, Bianca Maniscalco, Jake Bowers, Chakrabarty Chandan Kumar, and Marayati Bte Marsadek. 2019. "Formation of Moox Barrier Layer Under Atmospheric Based Condition to Control Mose2 Formation in CIGS Thin Film Solar Cell". figshare. https://hdl.handle.net/2134/35318. 
Kam Hoe Ong ${ }^{a^{*}}$, Ramasamy Agileswari ${ }^{\mathrm{a}}$, Panagiota Arnou ${ }^{\mathrm{b}}$, Biancamaria Maniscalco ${ }^{\mathrm{c}}$, Jake W. Bowers ${ }^{\mathrm{c}}$, Chakrabarty Chandan Kumar ${ }^{\mathrm{a}}$ and Marayati Bte Marsadek $^{\mathrm{d}}$

${ }^{a}$ Department of Electronics \& Communication Engineering, Universiti Tenaga Nasional, Selangor, Malaysia; wil_ng-okh@hotmail.com, Agileswari@uniten.edu.my, Chandan@uniten.edu.my

b Laboratory for Energy Materials, University of Luxembourg, L-4422 Belvaux, Luxembourg; panagiota.arnou@uni.lu

c Centre for Renewable Energy Systems Technology (CREST), Wolfson School of Mechanical, Electrical and Manufacturing Engineering, Loughborough University, Loughborough, Leicestershire, LE11 3TU, UK; biancamaria.maniscalco@gmail.com, J.W.Bowers@lboro.ac.uk

d Institute of Power Engineering, Universiti Tenaga Nasional, Selangor, Malaysia; Marayati@uniten.edu.my 


\title{
Formation of $\mathrm{MoO}_{\mathrm{x}}$ barrier layer under atmospheric based condition to control $\mathrm{MoSe}_{2}$ formation in CIGS thin film solar cell
}

\begin{abstract}
As part of the device fabrication process, selenization step is required to crystallise the CIGS absorber layer. However, during high temperature selenization process, excessive formation of $\mathrm{MoSe}_{2}$ can lead to delamination of the film and adverse effect on electrical properties of the solar cells. In this paper, a new method is proposed to form a Molybdenum Oxide $\left(\mathrm{MoO}_{\mathrm{x}}\right)$ barrier layer in between of the Mo back contact using plasma jet under atmospheric based conditions. The effect of $\mathrm{MoO}_{\mathrm{x}}$ compound $\left(\mathrm{MoO}_{2}\right.$ and $\left.\mathrm{MoO}_{3}\right)$ towards the efficiency of the device is investigated. It has been proven that a thin layer of $\mathrm{MoO}_{\mathrm{x}}$ barrier layer is able to control the formation of $\mathrm{MoSe}_{2}$ effectively and provide a significant improvement in electrical properties of the devices. A power conversion efficiency of 5.24\% with least efficiency variation across the champion device was achieved which demonstrates the importance of this methodology on small area devices.
\end{abstract}

Keywords: Copper Indium Gallium Selenide; CIGS thin film solar cells; $\mathrm{MoO}_{\mathrm{x}}$ barrier layer; atmospheric plasma jet; $\mathrm{MoSe}_{2}$

\section{Introduction}

Copper Indium Gallium Selenide (CIGS) has become one of the most promising absorber layer for thin film photovoltaic devices due to its high absorption coefficient for solar radiation and compatibility of its bandgap (1.6eV-1.0eV) [1]. With an impressive progression made in recent years, CIGS solar cells currently holds a record efficiency of 22.6\% which is the highest efficiency for thin film solar cells approaching Si [2].

As part of the device fabrication process, deposition of a thin-film of CIGS absorber layer followed by a selenization step is required to obtain highly crystallised material. The molybdenum (Mo) back contact typically reacts partially with selenium (Se) to form an intermediate $\mathrm{MoSe}_{2}$ layer at the Mo/CIGS interface during the selenization process [3], [4]. The MoSe 2 layer is believed to improve the adhesion between Mo and CIGS [5]-[7]. It forms 
a back surface field which can hinder the recombination of electrons and holes due to $\mathrm{MoSe}_{2}$ has a wider bandgap of $1.41 \mathrm{eV}$ than the CIGS absorber layer [8]-[10]. The $\mathrm{MoSe}_{2}$ layer also creates a favourable ohmic-type contact with resistivities as low as $10^{-3} \Omega \mathrm{cm}$ at the Mo/CIGS interface [8], [11], [12].

However, during the high temperature selenization process (above 723K), the reaction between Mo and Se can cause Mo back contact to react fully with Se to form a thick layer of $\mathrm{MoSe}_{2}$ [3]. Excessive formation of $\mathrm{MoSe}_{2}$ can lead to delamination of the film and adverse effect on open circuit voltage $\left(\mathrm{V}_{\mathrm{oc}}\right)$ and Fill factor (FF) of the CIGS solar cells due to high resistance of the $\mathrm{MoSe}_{2}$ [13], [14]. A thinner $\mathrm{MoSe}_{2}$ layer can be achieved by reducing the selenization temperature and duration, but this may affect the crystallisation of the CIGS absorber layer. A barrier layer can be deposited in between of the Mo back contact to control the Se diffusion and the growth of $\mathrm{MoSe}_{2}$ [15]-[17]. Molybdenum Nitride $\left(\mathrm{MoN}_{\mathrm{x}}\right)$ or Molybdenum dioxide $\left(\mathrm{MoO}_{2}\right)$ thin films with a thickness of $10 \mathrm{~nm}$ to $250 \mathrm{~nm}$ formed under vacuum based condition was used as a barrier layer [17], [18]. However, vacuum based approaches are typically costly, consumes very high energy and possesses low material utilisation, whereas atmospheric based approaches offered low cost and uniform deposition on thin films [19]. In addition, the effect of the barrier layers has on the efficiency of the solar cell is yet to be determined.

Therefore, considering the above mentioned, this paper proposes a new method to form a Molybdenum Oxide $\left(\mathrm{MoO}_{\mathrm{x}}\right)$ barrier layer in between of the Mo back contact using plasma jet under atmospheric based conditions. A thin $\mathrm{MoO}_{\mathrm{x}}$ barrier layer is applied in order to control the thickness of $\mathrm{MoSe}_{2}$ and also to improve the $\mathrm{J}-\mathrm{V}$ characteristics of the devices. Two types of barrier layers were deposited under vacuum based $\left(\mathrm{MoN}_{\mathrm{x}}\right)$ and atmospheric based conditions $\left(\mathrm{MoO}_{\mathrm{x}}\right)$ upon comparison purposes. Each set of films were completed in devices and were characterised. The effect of the barrier layers has on the solar cell performance is also discussed. 


\section{Experimental details}

\subsection{Formation of the $\mathrm{MoO}_{x}$ barrier layer}

The substrates used in this project were Molybdenum (Mo) coated soda lime glass (SLG) provided by AimCore Technology Co., Ltd. The substrates have a Mo thickness of $\sim 600$ nm with resistivity about $1.6 \times 10^{-5} \Omega \mathrm{cm}$. An atmospheric plasma jet was used to form the $\mathrm{MoO}_{\mathrm{x}}$ barrier layer under room temperature. A 5cm x 5cm Molybdenum coated glass (MoC) was first placed on a moveable stage and using helium gas, the oxygen gas was confined into plasma state while flowing through the discharge section. The plasma then passes through the nozzle to oxidise the surface of the Molybdenum coated glass (MoC). The setup of the atmospheric plasma jet is shown in Figure 1. Two different sample sets were processed. During the first set, the oxidation cycle and oxygen flow rate were varied from 3 to 6 and 20 SCCM to 40 SCCM respectively while the helium gas flow rate and voltage applied remained constant. The four samples from the first phase will be further characterized to determine which parameters should be altered. For the second set of the samples, oxygen flow rate and the applied voltage were increased from 40 SCCM to 60 SCCM and from $13.4 \mathrm{kV}$ to $26.2 \mathrm{kV}$ respectively while the oxidation cycle and helium gas flow rate remained constant. The oxidizing conditions of the atmospheric plasma jet are shown in Table 1. Mo 3, Mo 4 and Mo 8 were shortlisted to be processed in the next stage in section 2.2.

Figure 1. Atmospheric Plasma Jet

Table 1: Atmospheric Plasma Jet Oxidizing Condition

\section{2 Deposition of the top layer Molybdenum back contact}


After oxidizing the surface of the Molybdenum coated glass (MoC), an additional layer of Molybdenum back contact was deposited onto the selected samples (Mo 3, 4 and 8) by DC magnetron sputtering in a Nordiko DC magnetron sputtering system. The Mo target used in the Nordiko system which has a size of 300mm x100mm with $99.99 \%$ purity was supplied by the Testbourne Ltd. The oxidized MoC samples were mounted on a six slotted ( $5 \mathrm{~cm}$ x $5 \mathrm{~cm}$ for six samples) sample holder $\sim 10 \mathrm{~cm}$ away from the target. The deposition was done at system base pressure of $1.6 \times 10^{-6}$ Torr with Argon (Ar) gas flow rate of 2 SCCM. The power used was $1790 \mathrm{~W}$ and the working pressure applied was 1.4 mTorr. The deposition time for the top Mo layer was 2 min and during the deposition process, the sample holder was rotated at 3 revolutions per minute (rpm).

\section{3 Film preparation and selenization}

The samples with top Mo layer (two $2.5 \mathrm{~cm}$ x $2.5 \mathrm{~cm}$ samples from each) were proceeded to a less aggressive selenization process (shorter selenization duration) inside a tube furnace to observe the performance of the $\mathrm{MoO}_{\mathrm{x}}$ barrier layer. The two $2.5 \mathrm{~cm}$ x $2.5 \mathrm{~cm}$ samples were placed inside a graphite box with $\sim 300 \mathrm{mg}$ of selenium (Se) pellets. The tube furnace was first purge with nitrogen gas followed by setting up the starting pressure at $58.4 \mathrm{kPa}$. The heating profile lasted for $30 \mathrm{~min}$ which resulted in complete evaporation of the Se pellets in the box.

The remaining two $2.5 \mathrm{~cm} \times 2.5 \mathrm{~cm}$ samples were used as the substrates for spray deposition of CIGS precursor which consists of $\operatorname{In}_{2} \mathrm{~S}_{3}, \mathrm{Cu}_{2} \mathrm{~S}$ and $\mathrm{Ga}$ [20]. The spray deposition was conducted in ambient atmospheric condition within a fume hood using a glass chromatography atomizer. The targeted film composition based on the CIGS precursor solution with GGI $=0.3$ was $\mathrm{Cu}=$ $0.9, \mathrm{In}=0.7, \mathrm{Ga}=0.3$ and $\mathrm{Se}=2$. Then, a post-deposition selenization was 
performed similarly to the condition mentioned above just that the duration of heating profile used was $50 \mathrm{~min}$.

\section{4 Fabrication of CIGS solar cells}

The devices prepared in this project were deposited in standard stack configuration of $\mathrm{ZnO}: \mathrm{Al} / \mathrm{iZnO} / \mathrm{CdS} / \mathrm{CIGS} / \mathrm{Mo} / \mathrm{MoO}_{\mathrm{x}} / \mathrm{MoC}$ as shown in Figure 2. The substrates used were MoC and the surface of the MoC was oxidized followed by a deposition of a top Mo layer by DC magnetron sputtering. The CdS layer which has a thickness of $\sim 60 \mathrm{~nm}$ was deposited via chemical bath deposition. Whereas, the intrinsic $\mathrm{ZnO}$ and $\mathrm{Al}$ doped $\mathrm{ZnO}$ layers which have a thickness of $\sim 80 \mathrm{~nm}$ and $500 \mathrm{~nm}$ respectively were both deposited using Radio Frequency (RF) sputtering. Mechanical scribing was then carried out to isolate each cell $(2.5 \mathrm{~cm} \times 2.5 \mathrm{~cm})$ into grids with an area of $0.05 \mathrm{~cm}^{2}$.

\section{Figure 2. CIGS solar cell structure}

\section{5 Characterization}

A K-Alpha X-ray Photoelectron Spectrometer (XPS) system was used to determine the composition of the surface of the oxidized MoC. The cross-sectional view of the devices was analysed using a Carl Zeiss 1530 VP field emission gun scanning electron microscope (SEM). The aperture size was $30 \mu \mathrm{m}$ and the operating voltage was $5 \mathrm{kV}$. The current density/voltage ( $\mathrm{J}-\mathrm{V})$ characterization was performed using an in-house solar simulator under $1000 \mathrm{~W} / \mathrm{m}^{2}$ illumination.

\section{Results and discussion}

\section{1 XPS Analysis}

A high resolution XPS analysis was performed on the treated samples in Section 2.1. The results are shown in Table 2. It is shown that the barrier layers formed using the 
atmospheric plasma jet contain two types of $\mathrm{MoO}_{\mathrm{x}}$ which are $\mathrm{MoO}_{2}$ and $\mathrm{MoO}_{3} \cdot \mathrm{MoO}_{2}$ has been reported as a semiconductor while $\mathrm{MoO}_{3}$ as an insulator [21]. $\mathrm{MoO}_{2}$ has previously been used as a barrier layer to block Se diffusion during selenization [22]. However, the ratio of the $\mathrm{MoO}_{\mathrm{x}}$ compounds needed and importance of the $\mathrm{MoO}_{3}$ in the barrier layers are yet to be defined. In Table 2, the reference sample (MoC) has the highest metal atomic percentage and a majority of $\mathrm{MoO}_{2}$ before undergoing any oxidation process. The samples Mo 1 to Mo 4 have majority of $\mathrm{MoO}_{3}$ while Mo 3 and Mo 4 have decent amount of $\mathrm{MoO}_{2}$. The trend from first set of samples showed that increasing cycle will lead to decrease in amount of $\mathrm{MoO}_{2}$ and increase in amount of $\mathrm{MoO}_{3}$. Increasing oxygen flow rate showed opposite trend which was increased in amount of $\mathrm{MoO}_{2}$ and decreased in amount of $\mathrm{MoO}_{3}$. During the second set samples, increased applied voltages yielded to an initial increase in the amount of $\mathrm{MoO}_{3}$ from $17.31 \%$ to $24 \%$. Then, a further increase in oxygen flow rate has caused a drastic decrease in $\mathrm{MoO}_{2}$ content until a point where the surface of sample Mo 8 was almost fully oxidized with very little amount of metal left. Samples Mo 3, 4 and 8 were selected for top Mo layer deposition followed by a less aggressive selenization process for $30 \mathrm{~min}$.

Table 2: High Resolution XPS Summary table

\section{2 SEM analysis on the selenized samples and corresponding devices}

SEM analysis was performed on three groups of samples which consist of the untreated samples, sample with Molybdenum Nitride $\left(\mathrm{MoN}_{\mathrm{x}}\right)$ barrier layer and the samples with $\mathrm{MoO}_{\mathrm{x}}$ barrier layers as shown in Figure 3. The area within the dotted line indicated the thickness of $\mathrm{MoSe}_{2}$ formed. Due to the treatment affecting only the very top surface of the samples, the barrier layers between the $\mathrm{MoSe}_{2}$ and Mo are hardly to be observed from the SEM images. Nonetheless, the barrier layers were shown to be effective for controlling the formation of $\mathrm{MoSe}_{2}$. In Figure 3(a)., the entire Mo thickness of the MoC 
reacted with Se during the selenization. The thickness of $\mathrm{MoSe}_{2}$ formed was $2.17 \mu \mathrm{m}$ which is 7 times higher as compare to other samples. The sample in Figure 3(b). which has a configuration of MoC/Mo without any barrier layer showed delamination.

Figure 3. SEM cross-section images for samples (30min selenization) (a) MoC (untreated sample) (b) MoC/Mo (untreated sample) (c) MoN $\mathrm{M}_{\mathrm{x}}$ barrier layer (d) Mo 3 (e) Mo 4 (f) Mo 8

Result in Figure 3(c). corresponded to the sample with Molybdenum Nitride $\left(\mathrm{MoN}_{\mathrm{x}}\right)$ barrier layer. The inclusion of the respective result was intended to make a comparison between different types of barrier layers formed in different condition such as atmospheric based and vacuum based process. The MoNx barrier layer between $\mathrm{MoSe}_{2}$ and Mo in Figure 3(c). was formed using the DC magnetron sputtering system (vacuum based) with argon to nitrogen gas flow rate of 10:5 SCCM for 2 min. The $\mathrm{MoN}_{\mathrm{x}}$ barrier layer was used effectively to control the formation of $\mathrm{MoSe}_{2}$ to $300 \mathrm{~nm}$ at the same time the bottom Mo layer was remained unreacted to selenium. Samples from (d) - (f) which have the MoOx barrier layers worked accordingly to control the formation of $\mathrm{MoSe}_{2}$. The platelets formation on the surface of Figure 3(d). and (f) samples were due to non-uniformities of the MoSe layer. From Figure 3(d). to (e)., the thickness of $\mathrm{MoSe}_{2}$ reduction was due to the longer oxidation duration (thicker $\mathrm{MoO}_{\mathrm{x}}$ barrier layer). In sample (f), the thickness of $\mathrm{MoSe}_{2}$ does not reduce further despite using a higher oxygen flow rate during the oxidation process. Hence, the reduction of the $\mathrm{MoSe}_{2}$ thickness with $\mathrm{MoO}_{\mathrm{x}}$ barrier layer was attributed to the increase in the number of oxidation cycle but not the oxygen flow rate.

The cross-section SEM images of the corresponding solar cells (devices) are shown in Figure 4. Referring to Figure 4(a)., excessive formation of $\mathrm{MoSe}_{2}$ 
was observed in the untreated device (MoC). Whereas in the untreated device in Figure 4(b). (MoC/Mo), the $\mathrm{MoSe}_{2}$ was controlled at 210nm. This could be due to the surface of MoC being partly oxidized prior to any oxidation process. Devices in Figure 4(c). with $\mathrm{MoN}_{\mathrm{x}}$ barrier layers and (d) and (e) with $\mathrm{MoO}_{\mathrm{x}}$ barrier layers were able to control the formation of the $\mathrm{MoSe}_{2}$ layer while passivating the bottom Mo layer against selenization. On the other hand, barrier layer Mo 8 that has only $\mathrm{MoO}_{3}$ possessed an excessive formation of $\mathrm{MoSe}_{2}$ as shown in Figure 4(f). This result has shown that a thin layer of $\mathrm{MoO}_{3}$ alone is insufficient to suppress the formation of $\mathrm{MoSe}_{2}$. Among all devices, device $\mathrm{Mo} 3$ with $\mathrm{MoO}_{\mathrm{x}}$ barrier layer (5.78\% of $\mathrm{MoO}_{2}$ and $16.94 \%$ of $\mathrm{MoO}_{3}$ which means ratio of $\mathrm{MoO}_{2}: \mathrm{MoO}_{3}$ is 1:3) has the least $\mathrm{MoSe}_{2}$ formed which is $\sim 170 \mathrm{~nm}$. To further explain this behaviour, the following reactions and their corresponding Gibbs free energy were calculated from [23]:

$$
\begin{aligned}
& \mathrm{Mo}+\mathrm{Se}_{2} \rightarrow \mathrm{MoSe}_{2} \quad \Delta \mathrm{rG}^{\mathrm{o}}(800 \mathrm{~K})=-146 \mathrm{~kJ} / \mathrm{mol} \text { (favoured reaction) (1) } \\
& \mathrm{Mo}+\mathrm{O}_{2} \rightarrow \mathrm{MoO}_{2} \quad \Delta \mathrm{rG}^{\mathrm{o}}(800 \mathrm{~K})=-440 \mathrm{~kJ} / \mathrm{mol} \text { (favoured reaction) (2) } \\
& \mathrm{Mo}+\mathrm{O}_{3} \rightarrow \mathrm{MoO}_{3} \quad \Delta \mathrm{rG}^{\mathrm{o}}(800 \mathrm{~K})=-740 \mathrm{~kJ} / \mathrm{mol} \text { (favoured reaction) (3) } \\
& \mathrm{MoO}_{2}+2 \mathrm{MoO}_{3}+3 \mathrm{Se}_{2} \rightarrow 3 \mathrm{MoSe}_{2}+4 \mathrm{O}_{2} \quad \Delta \mathrm{rG}^{\mathrm{o}}(800 \mathrm{~K})=+1085 \mathrm{~kJ} / \mathrm{mol}
\end{aligned}
$$

(disfavoured reaction)

On the untreated device in Figure 4 (a)., the excessive formation of $\mathrm{MoSe}_{2}$ layer was caused by reaction 1 during selenization process. At $800 \mathrm{~K}$, both reaction 2 and 3 of Mo with $\mathrm{O}_{2}$ and $\mathrm{O}_{3}$ have lower Gibbs free energy than reaction 1 . The lower the Gibbs free energy, more likely the reaction will take 
place. The positive value for Gibbs free energy for the latter case (Reaction 4) shows that the $\mathrm{MoO}_{\mathrm{x}}$ barrier layer with both $\mathrm{MoO}_{2}$ and $\mathrm{MoO}_{3}$ can act effectively as a diffusion barrier to control the formation of $\mathrm{MoSe}_{2}$.

Figure 4. SEM cross-section images for devices (50min selenization) (a) MoC (untreated sample) (b) MoC/Mo (untreated sample) (c) $\mathrm{MoN}_{\mathrm{x}}$ barrier layer (d) Mo 3 (e) Mo 4 (f) Mo 8

\section{3 Statistical analysis of the devices}

The J-V characteristics measured from 6 solar cells of each sample $\left(0.25 \mathrm{~cm}^{2}\right)$ have been organized into box plots as shown in Figure 5. The average efficiency of the MoC, MoC/Mo, MoN, Mo 3, Mo 4 and Mo 8 devices are 4.45\%, 5.07\%, 4.2\%, 5.24\%, 4.13\% and 4.19\% respectively. In Figure 5., the performance of the device MoC was decent in terms of its fill factor $(\mathrm{FF})$, open circuit voltage $\left(\mathrm{V}_{\text {oc }}\right)$ with an average efficiency of $4.45 \%$. However, the main issue of the MoC device is excessive formation of the $\mathrm{MoSe}_{2}$ causing delamination problem which deteriorates the electrical properties of the device (possess low $\mathrm{J}_{\mathrm{sc}}$. For the device MoC/Mo, its efficiency fluctuated between 4.5\% - 5.95\%. The large efficiency deviation occurred is due to uneven formation of the $\mathrm{MoSe}_{2}$ that lead to some of the Se reacted with the bottom Mo layer. This showed that the untreated device MoC/Mo without any $\mathrm{MoO}_{\mathrm{x}}$ barrier layer was not able to supress the growth of $\mathrm{MoSe}_{2}$ uniformly. In addition, it should be noted that precise control of efficiency in small area devices is a crucial aspect to be considered before moving into large scale production [24]. Although device $\mathrm{MoN}_{\mathrm{x}}$ has a consistent efficiency but the efficiency is relatively low at $4.01 \%-4.28 \%$ as compared to other devices. $\mathrm{MoN}_{\mathrm{x}}$ device with lowest $\mathrm{J}_{\mathrm{sc}}$ obtained is the main factor that affects the efficiency of the device despite having high $\mathrm{V}_{\text {oc }}$ and decent FF. This case also indicated that the $\mathrm{MoN}_{\mathrm{x}}$ barrier layer is very resistive by having 
a high series resistance $\left(\mathrm{R}_{\mathrm{s}}\right)$. For the champion device Mo 3 with $5.78 \%$ of $\mathrm{MoO}_{2}$ and $16.94 \%$ of $\mathrm{MoO}_{3}$, the contribution made is mainly on uniformity and thinnest formation of $\mathrm{MoSe}_{2}$ layer (170nm) which eventually lead to highest FF obtained and improved in $\mathrm{V}_{\text {oc }}$ as compared to the devices with $\mathrm{MoN}_{\mathrm{x}}$ barrier layer and devices without barrier layer. The bad performance on device Mo 4 with low FF was caused by a thicker $\mathrm{MoO}_{\mathrm{x}}$ barrier layer formed (resistive). The $\mathrm{MoO}_{\mathrm{x}}$ barrier in device Mo 4 was formed with more oxidation cycles. Whereas device Mo 8 with low FF and low $\mathrm{V}_{\text {oc }}$ was due to excessive formation of $\mathrm{MoSe}_{2}$.

Figure 5. Box plot of the devices (a) Efficiency (b) Fill factor (FF) (c) Voc (d) Jsc

\section{Conclusion}

During the selenization process, high temperature condition will lead to excessive formation of $\mathrm{MoSe}_{2}$ which deteriorates the electrical properties of the solar cells. Atmospheric plasma jet can be used to form the $\mathrm{MoO}_{\mathrm{x}}$ barrier layer which can effectively suppress the growth of $\mathrm{MoSe}_{2}$ and improve the efficiency of the solar cells in terms of JV characteristics. Atmospheric plasma jet oxidizing condition using cycle of 3, He flow rate of $3 \mathrm{SLM}, \mathrm{O}_{2}$ flow rate of $40 \mathrm{SCCM}$, frequency of $37.8 \mathrm{kHz}$ and p-p voltage of $13.4 \mathrm{kV}$ is able to form a $\mathrm{MoO}_{\mathrm{x}}$ barrier layer with $5.78 \%$ of $\mathrm{MoO}_{2}$ and $16.94 \%$ of $\mathrm{MoO}_{3}$. This $\mathrm{MoO}_{\mathrm{x}}$ barrier in device Mo 3 with $\mathrm{MoO}_{\mathrm{x}}$ ratio of $1: 3\left(\mathrm{MoO}_{2}: \mathrm{MoO}_{3}\right)$ has proven its ability to control the formation of the $\mathrm{MoSe}_{2}$ to $170 \mathrm{~nm}$ which was thinnest among all devices while preventing the bottom Mo layer to react with Se. The passivation effect occurred was due to the reaction between selenium and $\mathrm{MoO}_{2}$ and $\mathrm{MoO}_{3}$ (present in the $\mathrm{MoO}_{\mathrm{x}}$ ) being thermodynamically unfavourable at $800 \mathrm{~K}$. The effect of $\mathrm{MoO}_{\mathrm{x}}$ barrier on the efficiency and electrical properties of the complete devices have also been examined. The controlled thickness of $\mathrm{MoSe}_{2}$ in device Mo 3 has achieved the highest efficiency of $5.24 \%$ with least efficiency variation. The contribution is mainly on highest FF obtained 
and improved $\mathrm{V}_{\mathrm{oc}}$ as compared to the device with $\mathrm{MoN}_{\mathrm{x}}$ barrier layer and devices without barrier layer. Lastly, the conducted experiment has successfully verified the importance, practicality and potential of the surface oxidation $\mathrm{MoO}_{\mathrm{x}}$ barrier formed under atmospheric based condition to control $\mathrm{MoSe}_{2}$ formation, improve electrical properties ( $\mathrm{V}_{\text {oc }}$ and $\mathrm{FF}$ ) and provide a more precise and less variation efficiency on small area devices which is crucial before manufacturing CIGS into large scale production.

\section{Acknowledgements}

This research was under the project entitled "Flexible solar photovoltaics for commercial roof tops and rural communities in Malaysia” which involves collaboration between Loughborough University, UK and Universiti Tenaga Nasional, Malaysia. The authors would like to acknowledge British council Newton Fund (Application ID 216006343) for funding this work.

References

[1] T. D. Lee and A. Ebong, “Thin film solar technologies: a review,” 2015 12th Int. Conf. High-capacity Opt. Networks Enabling/Emerging Technol., pp. 1-10, 2015.

[2] P. Jackson, R. Wuerz, D. Hariskos, E. Lotter, W. Witte, and M. Powalla, "Effects of heavy alkali elements in $\mathrm{Cu}(\mathrm{In}, \mathrm{Ga}) \mathrm{Se}_{2}$ solar cells with efficiencies up to 22.6\%,” Phys. status solidi - Rapid Res. Lett., vol. 10, no. 8, pp. 583-586, Aug. 2016.

[3] Y. C. Lin, Y. T. Hsieh, C. M. Lai, and H. R. Hsu, "Impact of Mo barrier layer on the formation of MoSe2 in Cu(In,Ga)Se2 solar cells,” J. Alloys Compd., vol. 661, pp. 168-175, 2016.

[4] Q. Cao, O. Gunawan, M. Copel, K. B. Reuter, S. J. Chey, V. R. Deline, and D. B. Mitzi, "Defects in Cu(In,Ga)Se 2 chalcopyrite semiconductors: A comparative study of material properties, defect states, and photovoltaic performance,” $A d v$. Energy Mater., vol. 1, no. 5, pp. 845-853, 2011.

[5] A. Urbaniak and K. Macielak, "Chemical and Structural Characterization of Cu(In ,Ga)Se2/Mo Interface in Cu(In , Ga)Se2 Solar Cells.” 
[6] R. Würz, D. F. Marrón, and a Meeder, "Formation of an interfacial MoSe 2 layer in CVD grown CuGaSe 2 based thin film solar cells,” Thin Solid Films, vol. 432, pp. 398-402, 2003.

[7] B. P. Rand, J. Genoe, P. Heremans, and J. Poortmans, “The effect of Mo back contact ageing on Cu(In,Ga)Se2,” Prog. Photovolt Res. Appl., vol. 15, no. February 2013, pp. 659-676, 2007.

[8] N. Kohara, S. Nishiwaki, Y. Hashimoto, T. Negami, and T. Wada, "Electrical properties of the $\mathrm{Cu}(\mathrm{In}, \mathrm{Ga}) \mathrm{Se} 2 / \mathrm{MoSe} / \mathrm{Mo}$ structure,” Sol. Energy Mater. Sol. Cells, vol. 67, no. 1-4, pp. 209-215, 2001.

[9] K.-J. Hsiao, J.-D. Liu, H.-H. Hsieh, and T.-S. Jiang, "Electrical impact of MoSe2 on CIGS thin-film solar cells.,” Phys. Chem. Chem. Phys., vol. 15, no. 41, pp. 18174-8, 2013.

[10] J. B. Pang, Y. a. Cai, Q. He, H. Wang, W. L. Jiang, J. J. He, T. Yu, W. Liu, Y. Zhang, and Y. Sun, "Preparation and Characteristics of MoSe2 Interlayer in Bifacial Cu(In,Ga)Se2 Solar Cells,” Phys. Procedia, vol. 32, pp. 372-378, 2012.

[11] T. Wada, N. Kohara, S. Nishiwaki, and T. Negami, "Characterization of the Cu(In,Ga)Se2/Mo interface in CIGS solar cells,” Thin Solid Films, vol. 387, no. 1-2, pp. 118-122, 2001.

[12] M. I. Hossain and F. H. Alharbi, "Recent advances in alternative material photovoltaics,” Mater. Technol., vol. 28, no. 1-2, pp. 88-97, 2013.

[13] A. Polizzotti, I. L. Repins, R. Noufi, S.-H. Wei, and D. B. Mitzi, "The state and future prospects of kesterite photovoltaics,” Energy Environ. Sci., vol. 6, no. 11, p. 3171, 2013.

[14] Y. C. Lin, D. H. Hong, Y. T. Hsieh, L. C. Wang, and H. R. Hsu, "Role of Mo:Na layer on the formation of MoSe2 phase in $\mathrm{Cu}(\mathrm{In}, \mathrm{Ga}) \mathrm{Se} 2$ thin film solar cells,” Sol. Energy Mater. Sol. Cells, vol. 155, pp. 226-233, 2016.

[15] B. Shin, Y. Zhu, N. A. Bojarczuk, S. Jay Chey, and S. Guha, “Control of an interfacial MoSe2 layer in Cu2ZnSnSe4 thin film solar cells: 8.9\% power conversion efficiency with a TiN diffusion barrier,” Appl. Phys. Lett., vol. 101, no. 5, 2012.

[16] C. W. Jeon, T. Cheon, H. Kim, M. S. Kwon, and S. H. Kim, “Controlled formation of MoSe2 by MoNx thin film as a diffusion barrier against Se during selenization annealing for CIGS solar cell,” J. Alloys Compd., vol. 644, pp. 317323, 2015. 
[17] A. Duchatelet, G. Savidand, R. N. Vannier, and D. Lincot, “Optimization of MoSe2 formation for $\mathrm{Cu}(\mathrm{In}, \mathrm{Ga}) \mathrm{Se} 2-$ based solar cells by using thin superficial molybdenum oxide barrier layers,” Thin Solid Films, vol. 545, pp. 94-99, 2013.

[18] C. W. Jeon, T. Cheon, H. Kim, M. S. Kwon, and S. H. Kim, “Controlled formation of MoSe2 by MoNx thin film as a diffusion barrier against Se during selenization annealing for CIGS solar cell,” J. Alloys Compd., vol. 644, pp. 317323, 2015.

[19] M. P. Suryawanshi, G. L. Agawane, S. M. Bhosale, S. W. Shin, P. S. Patil, J. H. Kim, and A. V Moholkar, "CZTS based thin film solar cells: a status review," Mater. Technol., vol. 28, no. 1-2, pp. 98-109, 2013.

[20] P. Arnou, C. S. Cooper, SoňaUličná, A. Abbas, A. Eeles, L. D. Wright, A. V. Malkov, J. M. Walls, and J. W. Bowers, “Solution processing of CuIn(S,Se)2 and $\mathrm{Cu}(\mathrm{In}, \mathrm{Ga})(\mathrm{S}, \mathrm{Se}) 2$ thin film solar cells using metal chalcogenide precursors,” Thin Solid Films, vol. 633, pp. 76-80, 2016.

[21] J. Nam, Y. Kang, D. Kim, D. Baek, D. Lee, and J. Yang, “The oxidation effect of a Mo back contact on $\mathrm{Cu}(\mathrm{In}, \mathrm{Ga})(\mathrm{Se}, \mathrm{S}) 2$ thin-film solar modules,” Sol. Energy Mater. Sol. Cells, vol. 144, pp. 445-450, 2016.

[22] W. Li, X. Han, Y. Zhao, and S. Yang, "Pre-annealing induced oxide barrier to suppress the over-selenization of Mo contact,” J. Mater. Sci. Mater. Electron., vol. 27, no. 11, pp. 11188-11191, 2016.

[23] K. H. O. K. O. Kubaschewski, Thermochemical properties of inorganic substances, 2nd ed. Berlin: Springer-Verlag, 1991.

[24] J. Ramanujam and U. P. Singh, “Copper indium gallium selenide based solar cells - Review,” Energy Environ. Sci., vol. 10, pp. 1306-1319, 2017. 
Tables

Table 1: Atmospheric Plasma Jet Oxidizing Condition

\begin{tabular}{|c|c|c|c|c|c|}
\hline $\begin{array}{c}\text { Sample } \\
\text { Name }\end{array}$ & Cycle & $\begin{array}{c}\text { He Flow } \\
\text { (SLM) }\end{array}$ & $\begin{array}{c}\text { O Flow } \\
\text { (SCCM) }\end{array}$ & $\begin{array}{c}\text { Frequency } \\
\text { (kHz) }\end{array}$ & $\begin{array}{c}\text { p-p Voltage } \\
\text { (kV) }\end{array}$ \\
\hline \multicolumn{7}{|c|}{ First Set } \\
\hline Mo 1 & 3 & 3 & 20 & 37.8 & 13.4 \\
\hline Mo 2 & 6 & 3 & 20 & 37.8 & 13.4 \\
\hline Mo 3 & 3 & 3 & 40 & 37.8 & 13.4 \\
\hline Mo 4 & 6 & 3 & 40 & 37.8 & 13.4 \\
\hline \multicolumn{7}{|l|}{ Second Set } \\
\hline Mo 5 & 3 & 3 & 40 & 34.55 & 21.4 \\
\hline Mo 6 & 3 & 3 & 40 & 32.6 & 26.2 \\
\hline Mo 7 & 3 & 3 & 50 & 32.6 & 26.2 \\
\hline Mo 8 & 3 & 3 & 60 & 32.6 & 26.2 \\
\hline
\end{tabular}

Table 2: High Resolution XPS Summary table

\begin{tabular}{|c|c|c|c|c|}
\hline Sample Name & Me (\%) & $\mathbf{M o O}_{2}(\mathbf{\%})$ & $\mathbf{M o O}_{\mathbf{3}}(\mathbf{\%})$ & O1s (\%) \\
\hline MoC (Ref) & 46.19 & 23.53 & 11.65 & 18.63 \\
\hline \multicolumn{5}{|c|}{ First Set } \\
\hline Mo 1 & 7.68 & 2.23 & 22.16 & 67.92 \\
\hline Mo 2 & 8.15 & 1.89 & 22.63 & 67.32 \\
\hline Mo 3 & 13.88 & 5.78 & 16.94 & 63.4 \\
\hline Mo 4 & 11.4 & 5.27 & 17.31 & 66.02 \\
\hline \multicolumn{5}{|c|}{ Second Set } \\
\hline Mo 5 & 5.6 & 3 & 24.14 & 67.26 \\
\hline Mo 6 & 3.49 & 2.53 & 24.87 & 69.11 \\
\hline Mo 7 & 2.81 & 2.08 & 25.98 & 69.13 \\
\hline Mo 8 & 1.53 & 0 & 24.86 & 73.62 \\
\hline
\end{tabular}

*Me is Molybdenum metal

\section{Table Captions}

Table

Table 1 Atmospheric Plasma Jet Oxidizing Condition......................... 4

Table 2 High Resolution XPS Summary table........................... 7 


\section{Figures}

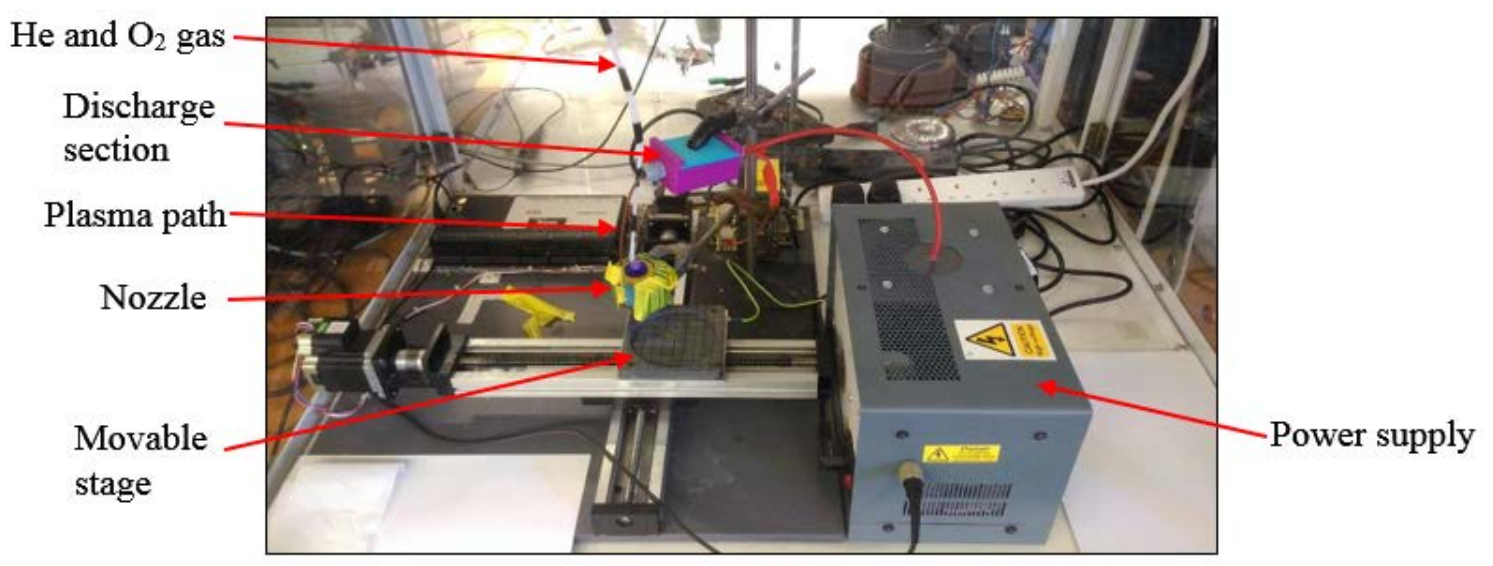

Figure 1. Atmospheric Plasma Jet

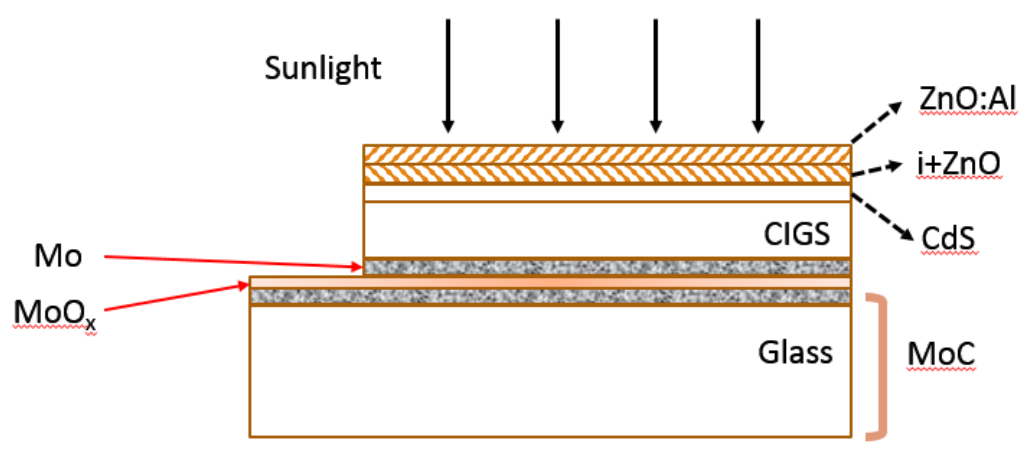

Figure 2. CIGS solar cell structure 

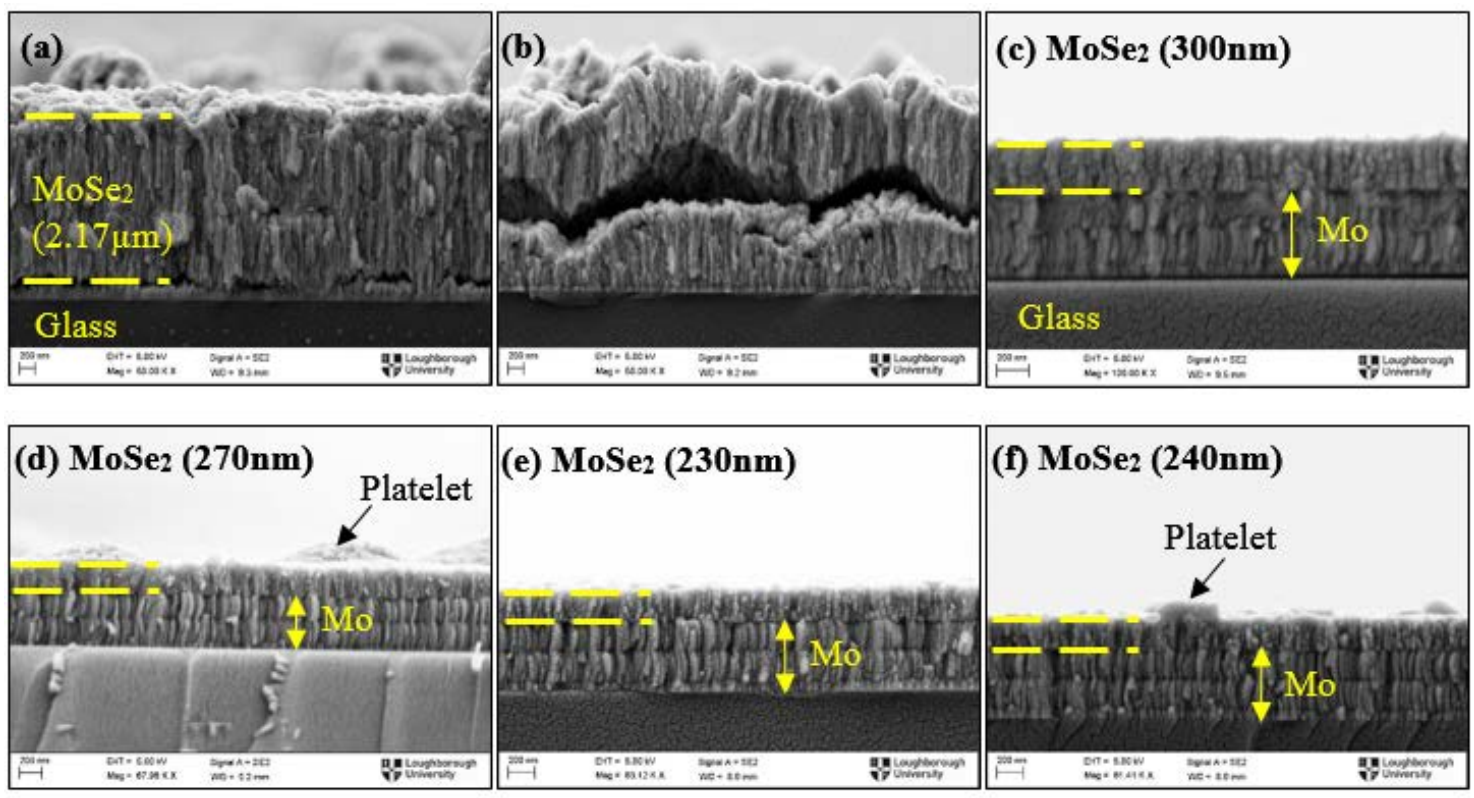

Figure 3. SEM cross-section images for samples (30min selenization) (a) MoC (untreated sample) (b) MoC/Mo (untreated sample) (c) $\mathrm{MoN}_{\mathrm{x}}$ barrier layer (d) Mo 3 (e) Mo 4 (f) Mo 8 


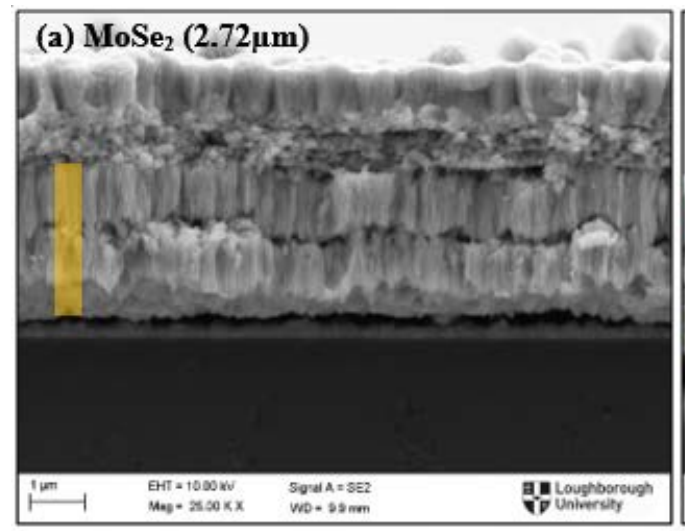

(b) $\mathrm{MoSe}_{2}(210 \mathrm{~nm})$
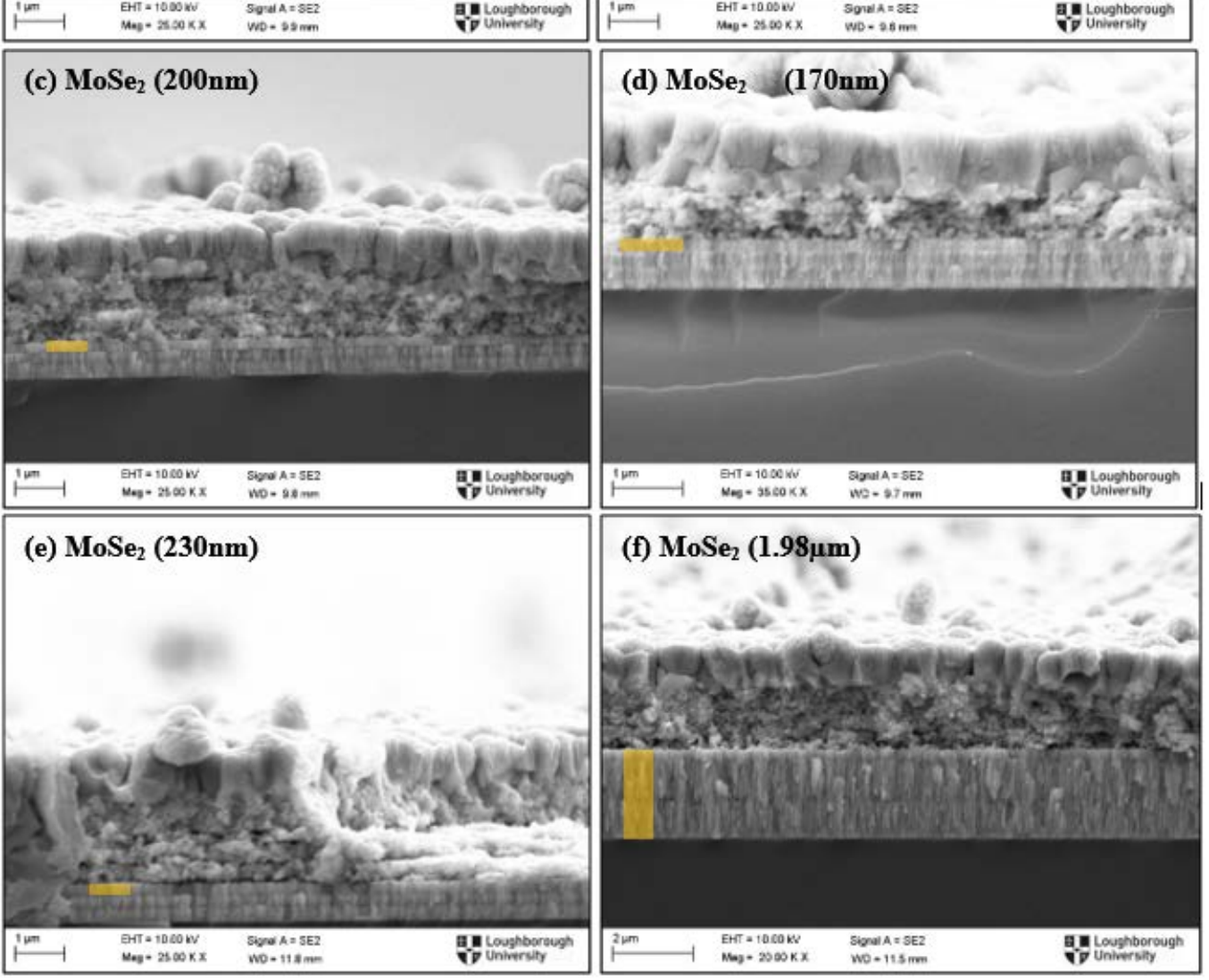

Figure 4. SEM cross-section images for devices (50min selenization) (a) MoC (untreated sample) (b) MoC/Mo (untreated sample) (c) $\mathrm{MoN}_{\mathrm{x}}$ barrier layer (d) Mo 3 (e) Mo 4 (f) Mo 8 

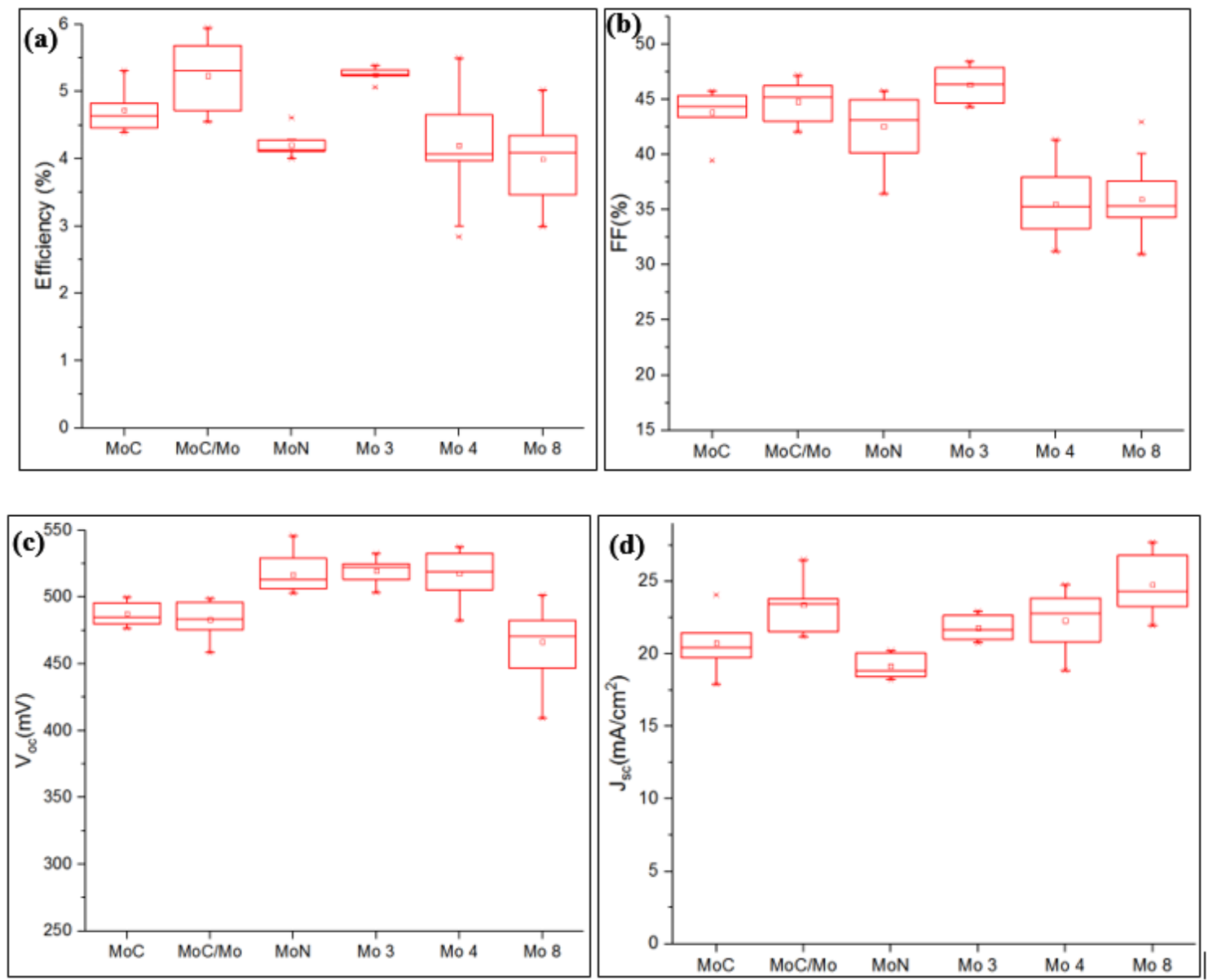

Figure 5. Box plot of the devices (a) Efficiency (b) Fill factor (FF) (c) Voc (d) Jsc

\section{List of Figures}

Figure

Page

Figure 1. Atmospheric Plasma Jet.........................................4

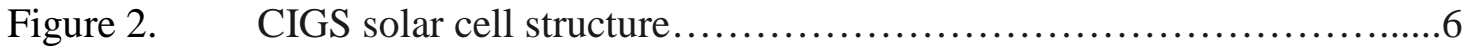

Figure 3. SEM cross-section images for samples (30min selenization) (a) MoC (untreated sample) (b) MoC/Mo (untreated sample) (c) $\mathrm{MoN}_{\mathrm{x}}$ barrier layer (d) Mo 3 (e) Mo 4 (f) Mo 8.................................8

Figure 4. SEM cross-section images for devices (50min selenization) (a) MoC (untreated sample) (b) MoC/Mo (untreated sample) (c) $\mathrm{MoN}_{\mathrm{x}}$ barrier layer (d) Mo 3 (e) Mo 4 (f) Mo 8..............................10

Figure 5. Box plot of the devices (a) Efficiency (b) Fill factor (FF) (c) Voc (d) Jsc. 